\title{
A PALIMPSEST OF PLACE. RENOVATION OF THE OLD STAROSTY COMPLEX AND MEDIEVAL CELLARS IN OLKUSZ
}

\author{
Grzegorz NAWROT \\ Faculty of Architecture, Silesian University of Technology
}

\section{Abstract}

The structure and methods of separating the space in consciously formed objects are a reflection of philosophical theories and historical processes, a specific emanation of the ocentricism, anthropocentrism and anti-centrism. Constructing the structure of an architectural object, i.e., separating space for it and within it, is determined by types of activities, methods, and purpose.

Keywords: renovation, architectonics, supra-architectural system, building anatomy

\section{THE DESIGN CONCEPT OF THE COMPLEX}

Design: 2015-2020

Project completion: 2020

Architecture: Grzegorz Nawrot (Chief Designer), Jerzy Witeczek, Aleksandra Witeczek

The renovation of the Complex began after nearly twenty years of the building being completely abandoned. Renovation of the historic buildings complex in 2017-2021, under Revitalisation of the Royal Quarter in Olkusz, including

\footnotetext{
${ }^{1}$ Corresponding author: Assoc. Prof. D.Sc. Ph.D. Arch. Grzegorz Nawrot, Department of Housing and Public Architecture Design, Faculty of Architecture, Silesian University of Technology in Gliwice, 44-100 Gliwice, Poland, e-mail: arch_grzegorz_nawrot@poczta.onet.pl; grzegorz.nawrot@polsl.pl, telephone: 602676 580,nr ORCID: 0000-0002-2704-4957
} 
reconstruction and extension of the building of the Old Starosty building and development of the historical complex area, was executed as a task co-financed from the European Regional Development Fund under the Regional Operational Programme of the Małopolskie Voivodeship for 2014-2020.

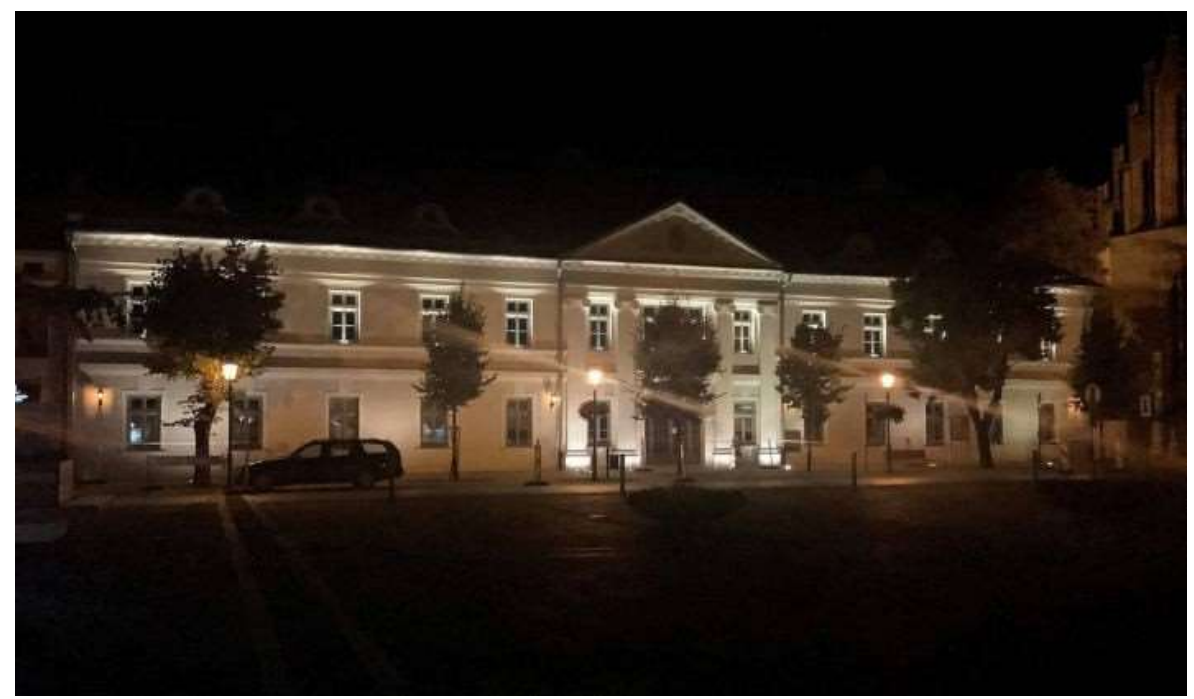

Fig. 1. Main façade, view from the Market Square, at night, after renovation (Photo by the author)

The works were performed on volumetric parts and involved land development. The historical complex of the Royal Quarter in Olkusz consists of the main building of the Old Starosty, a wall alley, a courtyard between the wall alley and the main building, relics of medieval cellars located under the main building and the courtyard, and a replica of the Olkusz defensive walls enclosing the space of the quarter interior (bastion, roof, walkways). The Old Starosty is situated on the site of the Royal Mint, which was in operation at the end of the 16th century. The building and its accompanying courtyard were constructed in 1828 , on the land occupied by four plots of market townhouses. The building was inserted into the existing southern frontage of the Market Square, on top of other elements of the earlier development. The only remnants of this are the cellars and the relics of walls and floors discovered during earlier archaeological and conservation [5] research and during the current construction.

The designed Complex includes the existing building of the Old Starosty, a new building-pavilion, an inner courtyard, cellars under the courtyard, relics of the defensive walls, and a wall alley. The following functions have been designed for the Complex: 


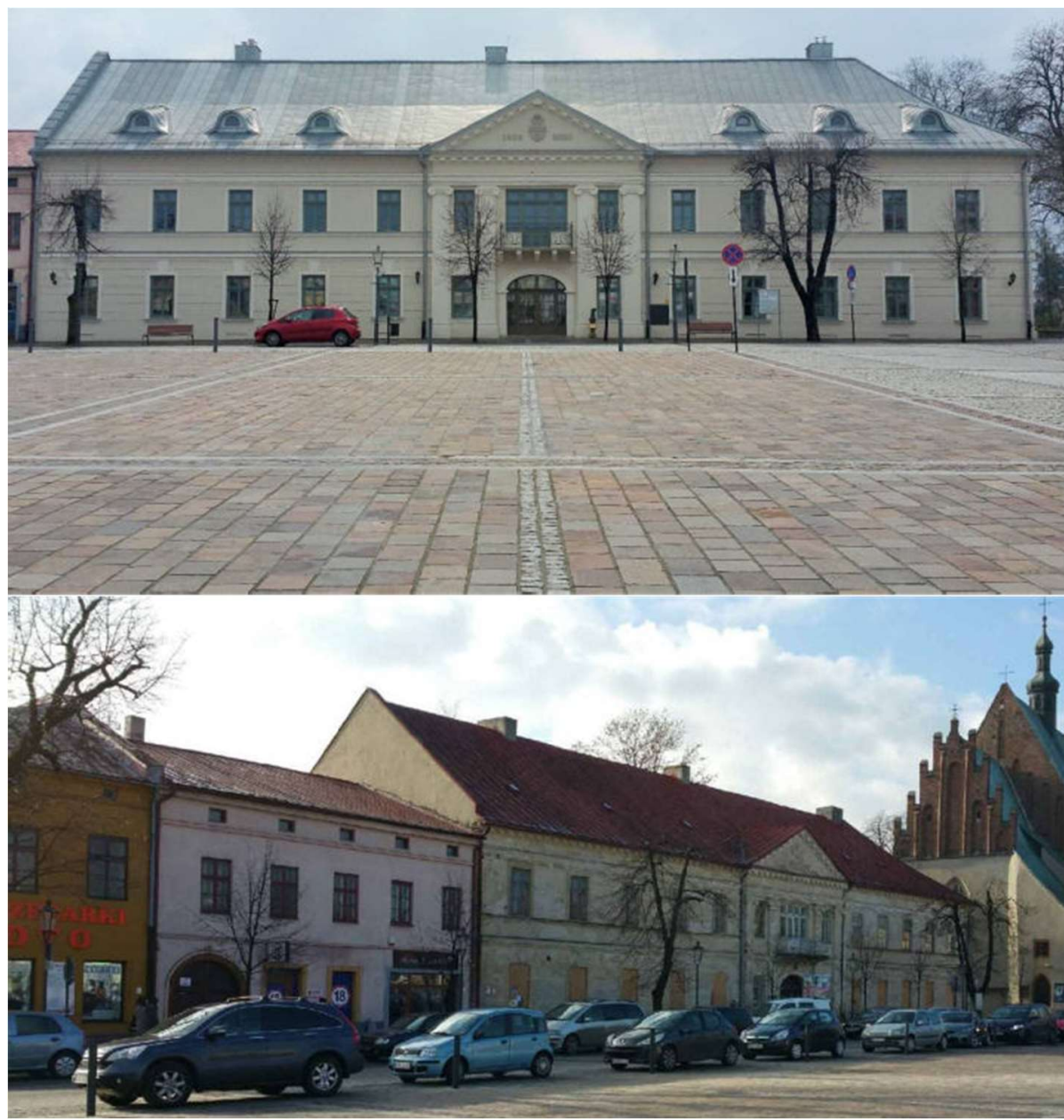

Fig. 2. Main façade, view from the Market Square, after and before renovation (Photo by the author)

Old Starosty building:

- temporary and permanent exhibitions (ground floor, first floor),

- venue for thematic workshops, conferences, symposia, chamber concerts, meetings (medieval cellars, first floor, attic),

- a restaurant and wine bar (ground floor) and an additional multifunctional room, which can also be used as a dining room for special events (first floor),

- gift shop with souvenirs and thematic materials (ground floor),

- administrative part (ground floor, first floor),

- accommodation for rent (attic). 


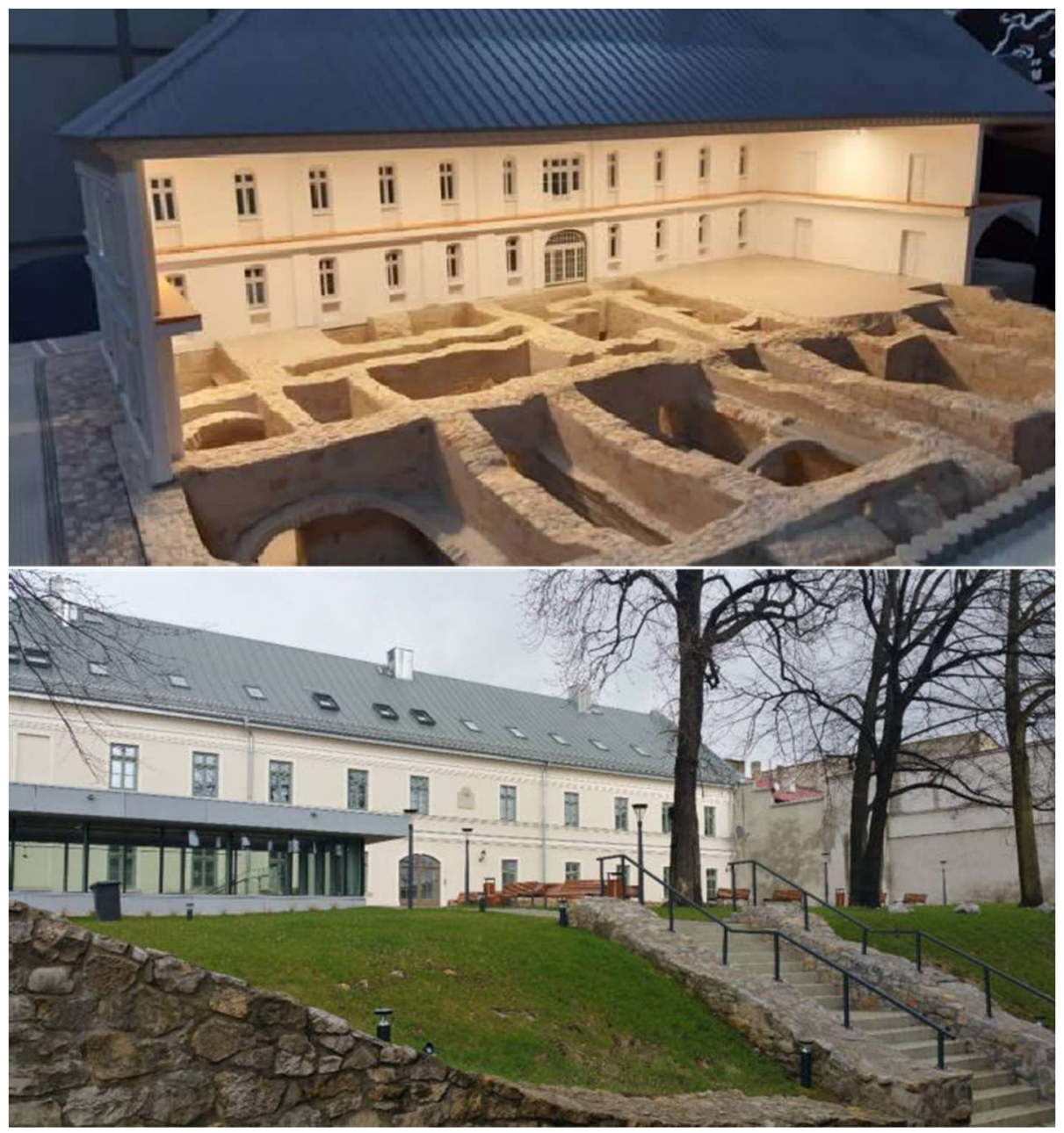

Fig. 3. The Complex seen from the courtyard. A miniature model and after completion (Photo by the author)

Newly designed building (exhibition pavilion):

- presentation of existing fragments - witnesses- temporary exhibitions.

Courtyard:

- a meeting place and a place for events animation, summer garden for restaurants, summer cinema. 

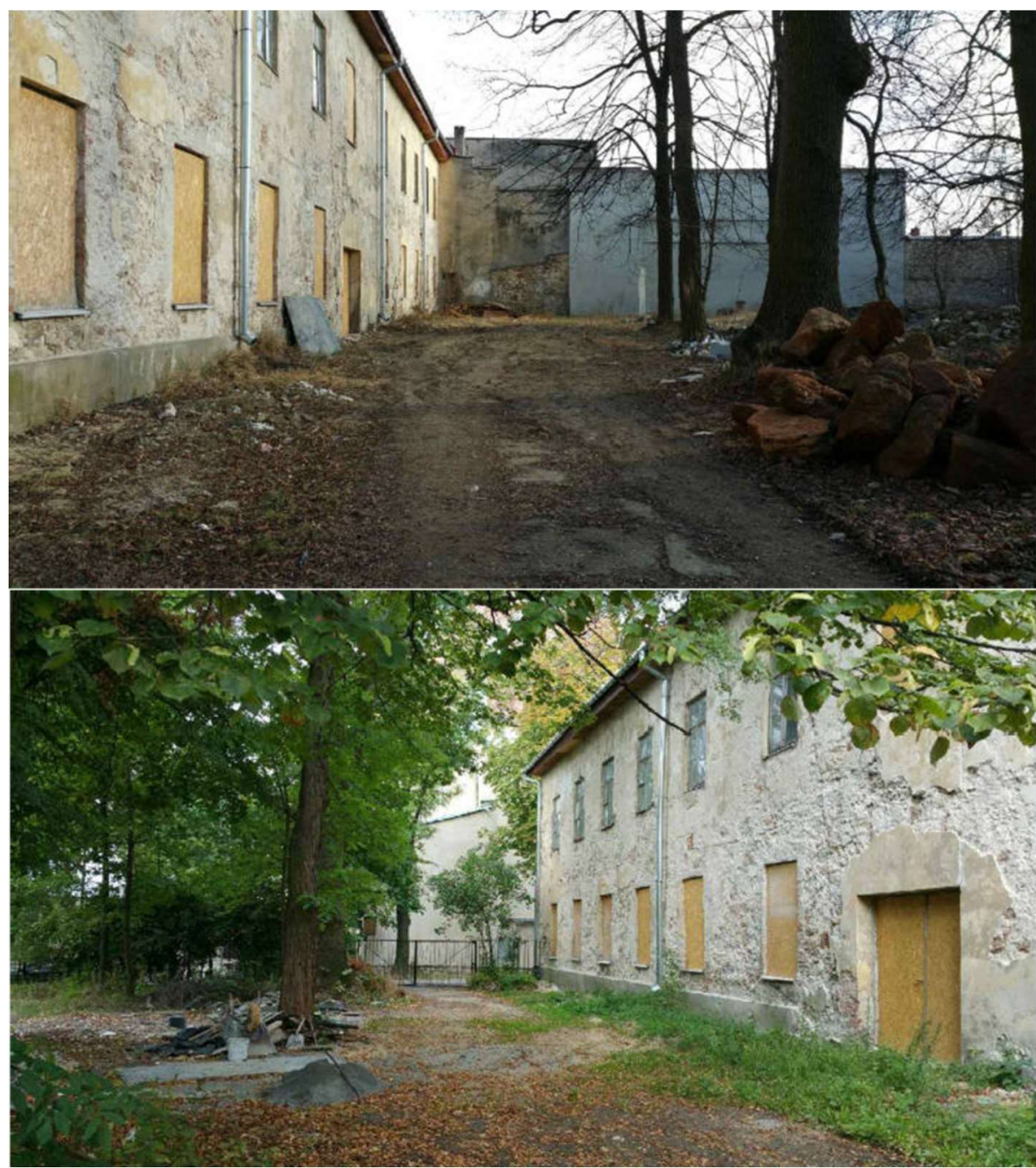

Fig. 4. Façade seen from the courtyard. Before renovation (Photo by the author)

Medieval cellars under the courtyard:

- presentation of existing fragments -witnesses,

- temporary exhibitions,

- space for thematic workshops, chamber concerts.

Relics of defensive walls, wall alley:

- not subject to thematic renovation. 


\section{DIRECTION-RELATED DECISIONS}

Key issues to be taken into account when formulating the direction of the future design of a historical building are:

- use,

- architectonics, i.e., the supra-architectural system shaping the separation of space,

- $\quad$ specific clothing of the object: the visual appearance or overall aesthetics of the object, including choices regarding the means of implementation technology, materials andstaffage.

Renovation of the space of a historical building or complex often involves a change of use. Such change occurs behind a specific historical façade constructed from the old content, name, elevation and spatial structure. That involves a reinterpretation of meaning. An object, functioning behind a façade of historical interpretations, is a means of conveying information and can reinterpret not only the former content but also signs that are its emanation. The structure of the whole and its elements then become carriers of content different from the historical one.

\section{USE. A PALIMPSEST OF PLACE. SUPERIMPOSING ON THE WRITTEN, LOOKING AT THE FAÇADE OF THE BODY OR INTO THE SOUL}

Everyone prefers belief to the exercise of judgement [Seneca] It is easier to judge a building by looking at its façades and interiors- by referring to the forms and signs recorded in memory, and to the corresponding meanings, believing in the permanence of associations, constituting the ontological security of moving around what, although apparently new, seems to be commonly known. That is not the case, however. More and more often, we move in the space, among what is seemingly known, but what turns out to be a new, content-related antonym, changing the meaning of the known. That happens in the face of the prevalently transforming organisation of social life and its material emanations, embedding the places of events that expressit.

The structure and methods of separating the space in consciously formed objects are a reflection of philosophical theories and historical processes, a specific emanation of the ocentricism, anthropocentrism and anti-centrism. Constructing the structure of an architectural object, i.e. separating space for it and within it, is 
determined by types of activities, methods, and purpose $[10]^{2}$. For architecture is also a way of identifying those through whom it is made, including those who finance its creation [9]. Therefore, the purpose is of crucial importance. When considering either a functioning individual spatial structure, an architectural object, or a city, we come to the conclusion that it is easier to shape their appearance, i.e. their anatomy, than their physiology (the way they work) [6]. A similar conclusion may apply to shaping this anatomy (body) and its nonmaterial, multifaceted emanation (soul). That is crucial in the case of a historical building. Making a decision that determines its future use and meaning suggests the question about the sense of the adapted body emanation in the transmission of this multifaceted emanation.

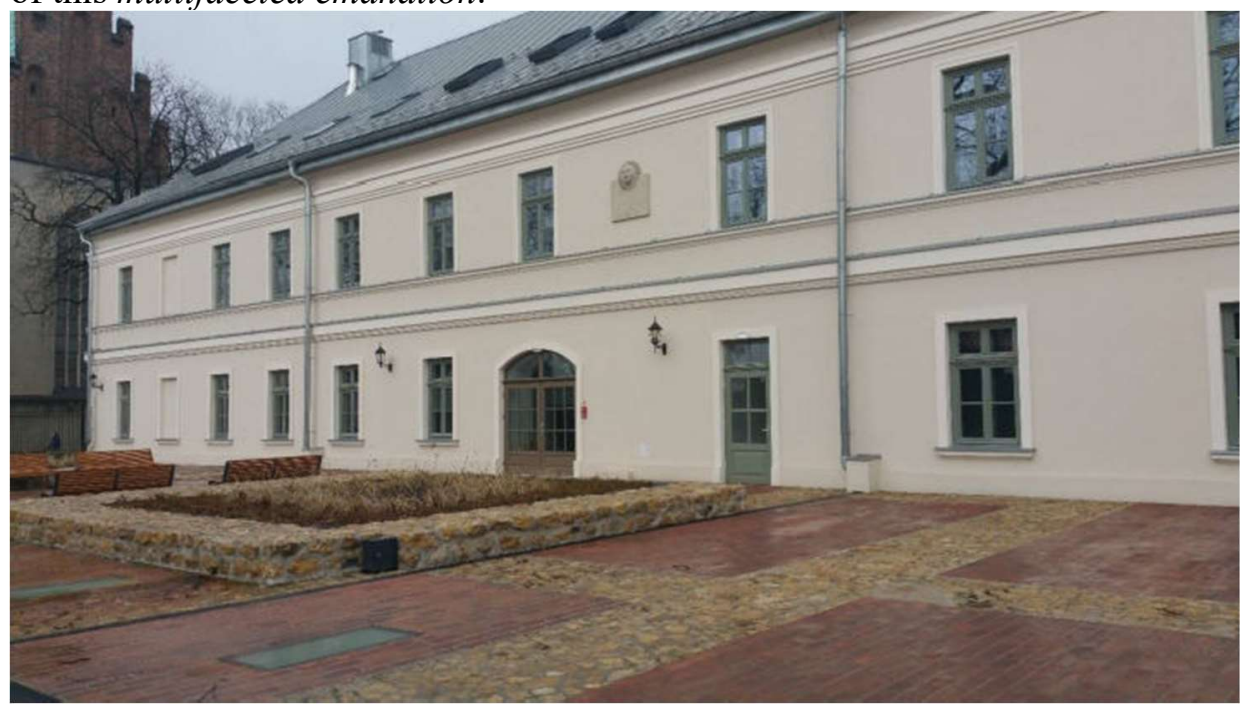

Fig. 5. Façade seen from the courtyard. After renovation (Photo by the author)

\footnotetext{
${ }^{2}$ Separating space, and therefore: constructing architecture. Among many definitions of architecture, the author uses the one formulated by Bruno Zevi, which he considers the most pertinent. Referring to the sociological definition according to Max Weber: In "action" is included all human behaviour when and insofar as the acting individual attaches a subjective meaning to it. Action in this sense may be either overt or purely inward or subjective; it may consist of positive intervention in a situation, or of deliberately refraining from such intervention or passively acquiescing in the situation. Action is social insofar as, by virtue of the subjective meaning attached to it by the acting individual (or individuals), it takes account of the behaviour of others and is thereby oriented in its course. Weber Max, Sociological Writings. Ed. by Wolf Heydebrand, publ. in 1994 by Continuum. According to the author, Max Weber's definition which refers actionmainly toactions by an individual, is most suitable in this case. After Nawrot Grzegorz, 2015.
} 
a)

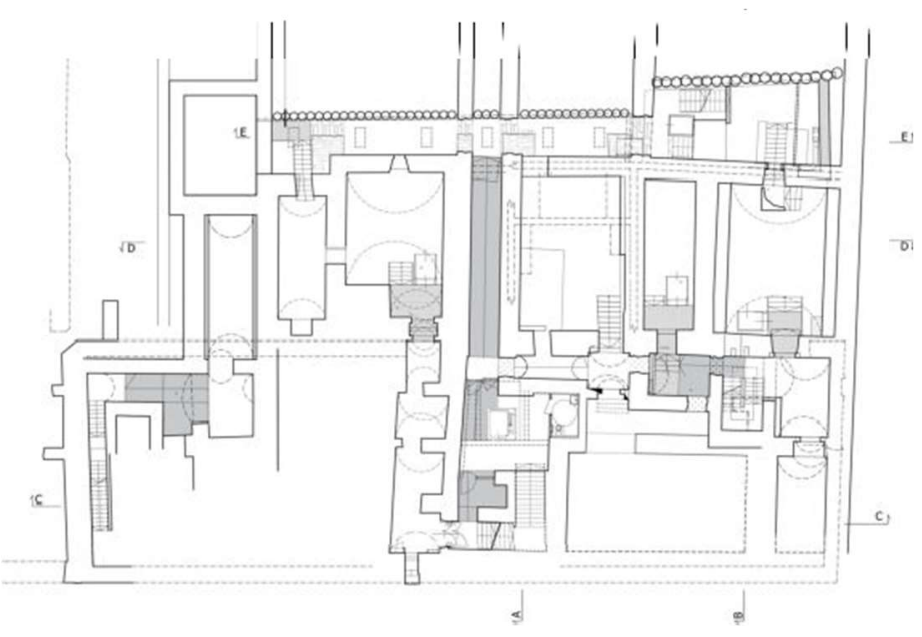

b)

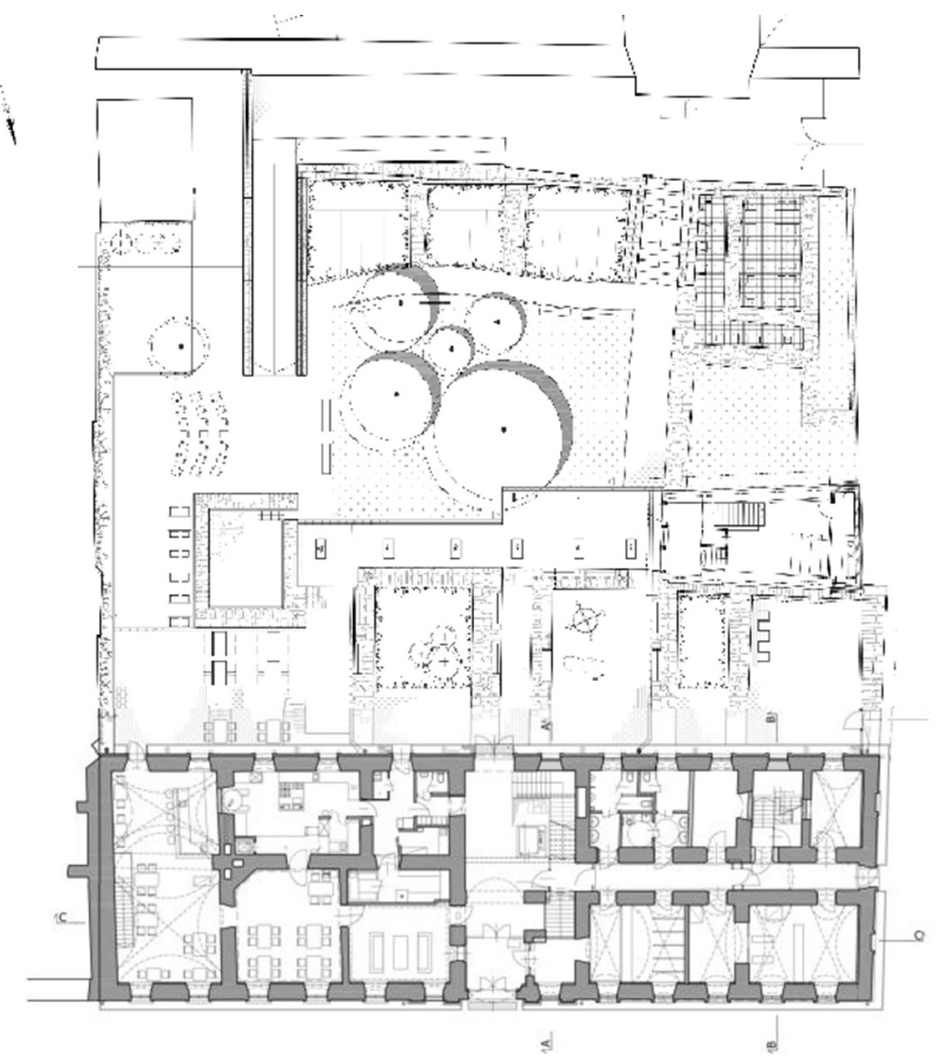


c)

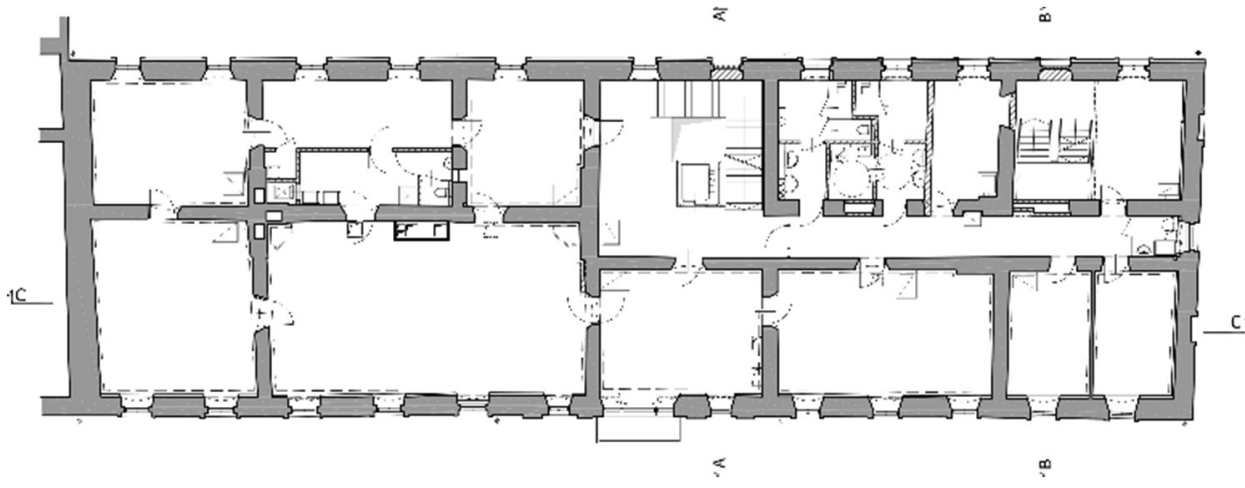

d)

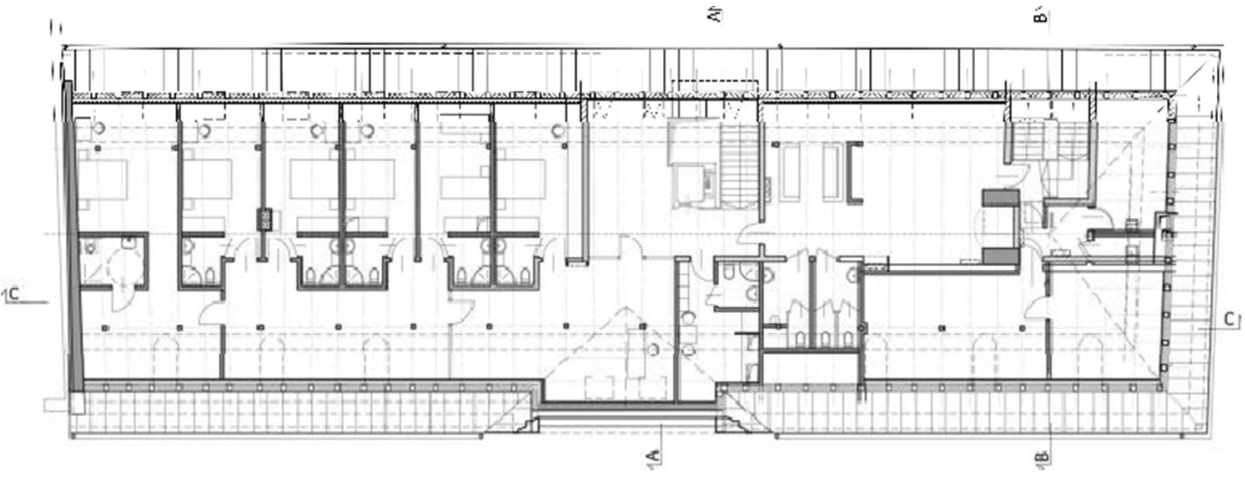

e)

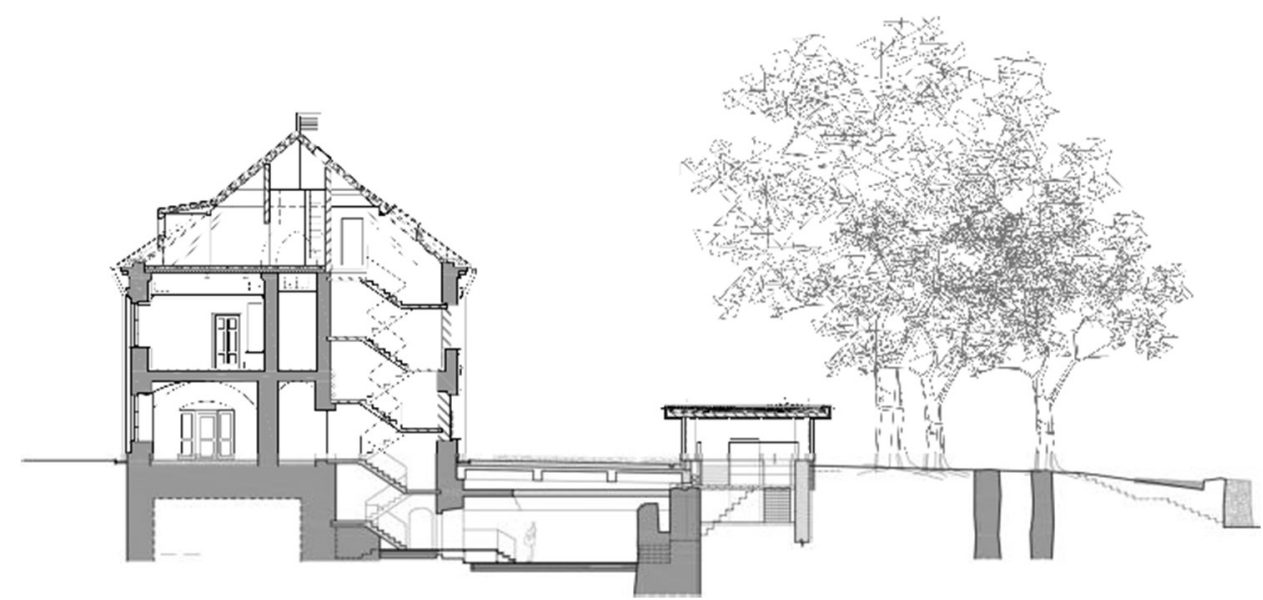

Fig. 6. Realised design. Layouts: basement (a), ground floor and courtyard ground floor with the exhibition pavilion (b) and first floor (c), attic (d); cross-section (e) 
Superimposing on the written, albeit diverse and at least ambiguous with regard to conveying historical truth - is often characteristic of revitalised historical spaces. The introduction of new elements, marking a contemporary difference from the historical ones or imitating them, reproducing a pretended historicity is difficult to avoid, regardless of the approach taken to constructing the concept. The superimposing may concern the material sphere or the interpretative one, i.e., the said looking at the body or into the soul.

Mortimer Jerome Adler points out that man can be in a threefold position with regard to an object: he can perceive it, recollect it or imagine it [1]. His relations with space may be realised in a similar way. The first and the third have a profound influence on the present construction of its concept. Perceiving implies imagining by showing or concealing. Recollecting is linked to reference to an understanding of the contemporary use of any historical space. Accepting, the interpretation of such use is a determinant of demonstrating, which indicates the historical truth or -subjectively interpreting - pretends it [7].Concealingsuggests a mystery, whether existing or merely imagined - prompting imagination.

Renovation of a historical space often involves a change of use. It is a kind of the urgy of re-animated space, its images and signs, evoking impressions that were once perhaps absent in it. It takes place behind the historical façade, constructed not so much from the materially renewed elements of the durable spatial structure and the elevation, but from the old content categorised ideologically by contemporary, often different from historically fixed, ontological interpretations. That involves a semantic reinterpretation of the entire space of the object or complex. An already contemporary object, functioning behind material façades of the historical elevations and spatial structure, since it is a kind of medium of the present-day information - can reinterpret not only the content but also the signs, which are its emanation. In the new functional structure, they become carriers of content different from the historical one.

\section{THE FAÇADE OF THE INTERPRETED CONTENT. REINTERPRETATION OF SIGNS. ONTOLOGICAL SECURITY}

The concept of renovation of a historical building is inextricably linked to the justification of the need for its existence in current conditions. That applies first of all to cultural values (meaning, history, aesthetics) but also economic ones. Reinterpretation of the usable content of an object is connected with the reinterpretation of meanings and reinterpretation of signs emanating them. The material content of the space of a monument reconstructed adequately to historical patterns, reinterpreted in terms of new content - becomes formatted, 
developing into a kind of background for the interpretation relevant to the contemporary context. The non-material, historical content - justifying the preservation and protection of the object, which was once contextually constructed to suit past needs, now losing its primary significance - becomes a kind of background - one of the elements of the staffage for interpreting the contemporary context of the object's purpose.

The unchanging façade hiding the newly interpreted content and the content representing it are a re-creation of the object's spatial structure: a kind of semantic deconstructivism - expressed in a different assignment of the new content to the old packaging and the old spatial design. In the case of some objects, the structure of the whole, so enlivened in a contemporary interpretation of reality, is usefully more reasonable than it would have been if reproduced in the historical reality of the monument.

\section{ARCHITECTONICS OR SUPRA-ARCHITECTURAL SYSTEM SHAPING THE STRUCTURE: RENOVATION OF CONTENT, RENOVATION OF FORM, RENOVATION OF SEPARATION OF THE SPACE}

The architectural space may be interpreted on three levels. The first, extraarchitectural, constructs a multidisciplinary model of the Idea, which also adequately shapes the concept of architecture. The second relates to spatialformal and aesthetic solutions. The third is the individually subjective interpretations made by individual observers.

The first, therefore, abstractly shapes the non-material structure of the composition of the Idea conveyed (contents, meanings, places, functions, aesthetics, etc.), giving it, for example, a compact or dispersed form. The second, being a material emanation of the first, constructs a corresponding material structure, for example, a philosophical metaphor of a compact edifice or a dispersed one - a compilation. The third is related to the experience of the observers. The categories truth or untruth, secrecy or openness, permanence or transience-apply to each of the three levels [7].

In most cases, the renovation of a historical building is the renovation of its content. The content consists of many different elements, but the key ones are the usable content (A), which is what the object was built for, and its specific packaging, which consists of a spatially constructed enclosure (B). The renovation of each of these elements affects the perception of the whole, as both the information about the content and its enclosure produce an image of the object in the observer. 


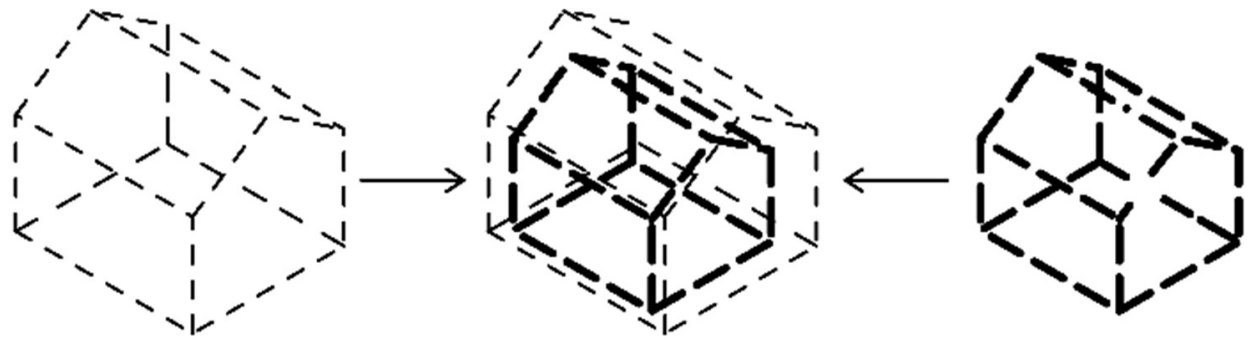

Fig. 7. The content and the content's enclosure. The façade hiding the interpreted content and the content representing it are a re-creation of the object's spatial structure: a kind of semantic deconstructivism - expressed in a different assignment of the new content to the old packaging and the old spatial design
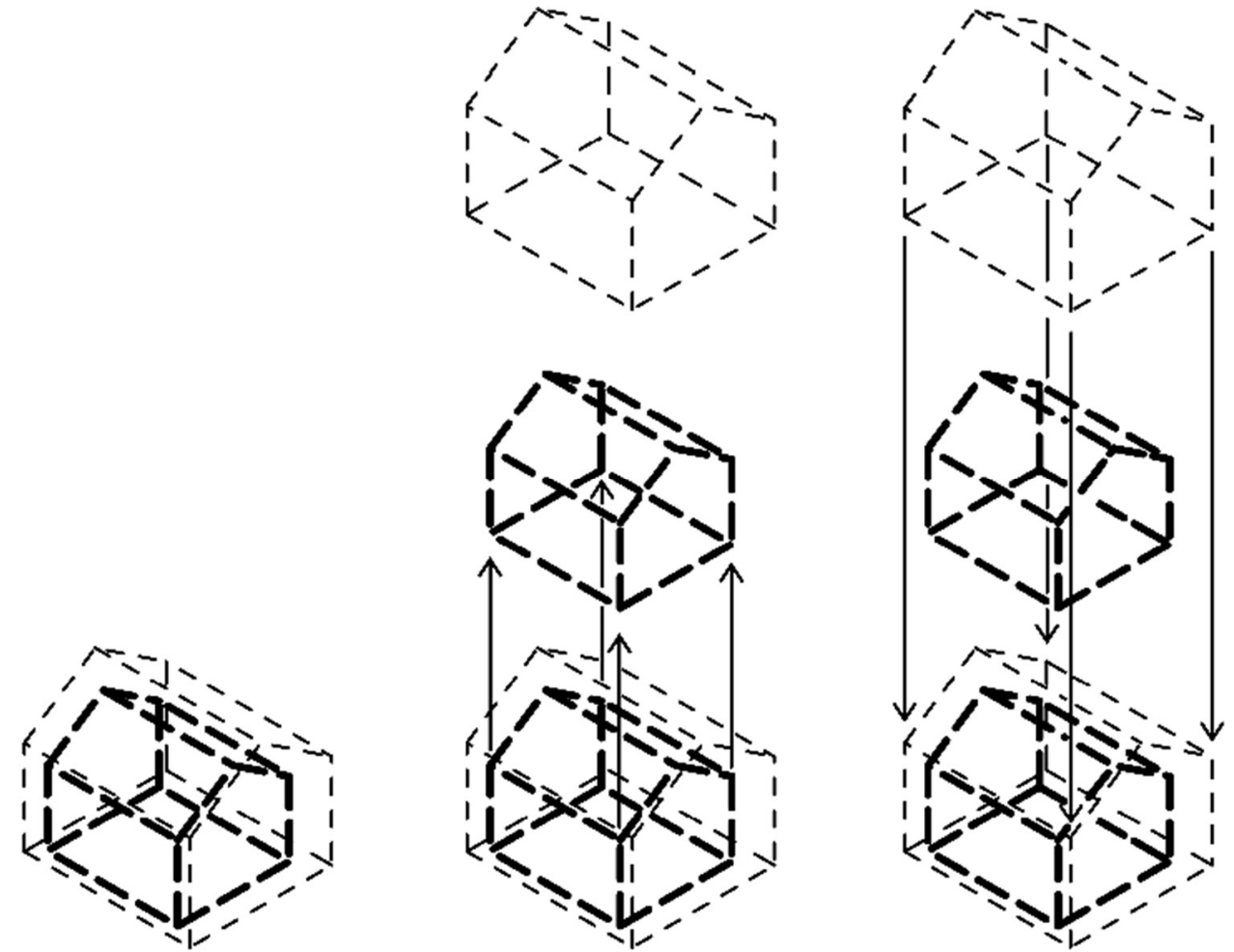

Fig. 8. Content replacement. An unchanging façade hiding new interpretations: the assignment of a new content to the old packaging and the old spatial structure 
A spatially constructed enclosure is not just a façade - it is the overall architectonics of the object, i.e., the adopted system of separating space for the location of the content, which determines the utility function of the building. Hidden behind the façade enclosure, it abstracts from the content $[4]^{3}$.

While the design of the façades and the architectonics are most often determined by the historical requirements of respecting the cultural heritage, the contentthanks to giving a new utilitarian meaning - is often a significant justification for the object preservation and continued existence.
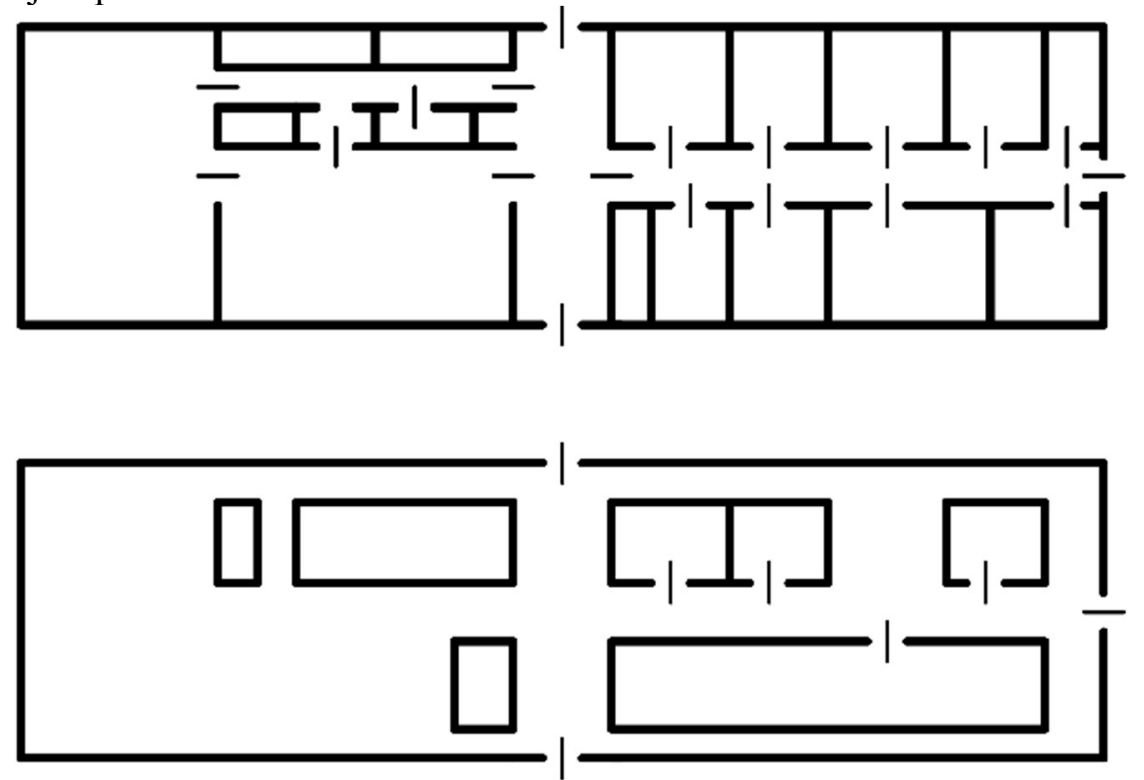

Fig. 9. Chronological and linear (designed in the object-upper figure) vs compilation (lower figure) shaping the space inside the object

\section{NEW CATEGORISATION OF THE SPACE}

In the Old Starosty, while planning the new content of the object, it was decidedboth in relation to the aboveground and underground parts - to preserve the existing or, failing that, to reconstruct the historical, compact structure of the

\footnotetext{
${ }^{3}$ According to Immanuel Kant: "Architectonics is art of constructing systems, i.e., unity of different cognitions subordinated to a certain idea, Kant Immanuel,1957; vol. II p. 577. Here-understood as the composition of a created system: the adopted principles of separating space, ordering the system of its spatial construction.
} 
internal space. The consequence of such an approach is a chronological and linear movement through sequentially separated parts of the object's interior, unambiguously ordering the permanent manner of use and unambiguous perception of its space.

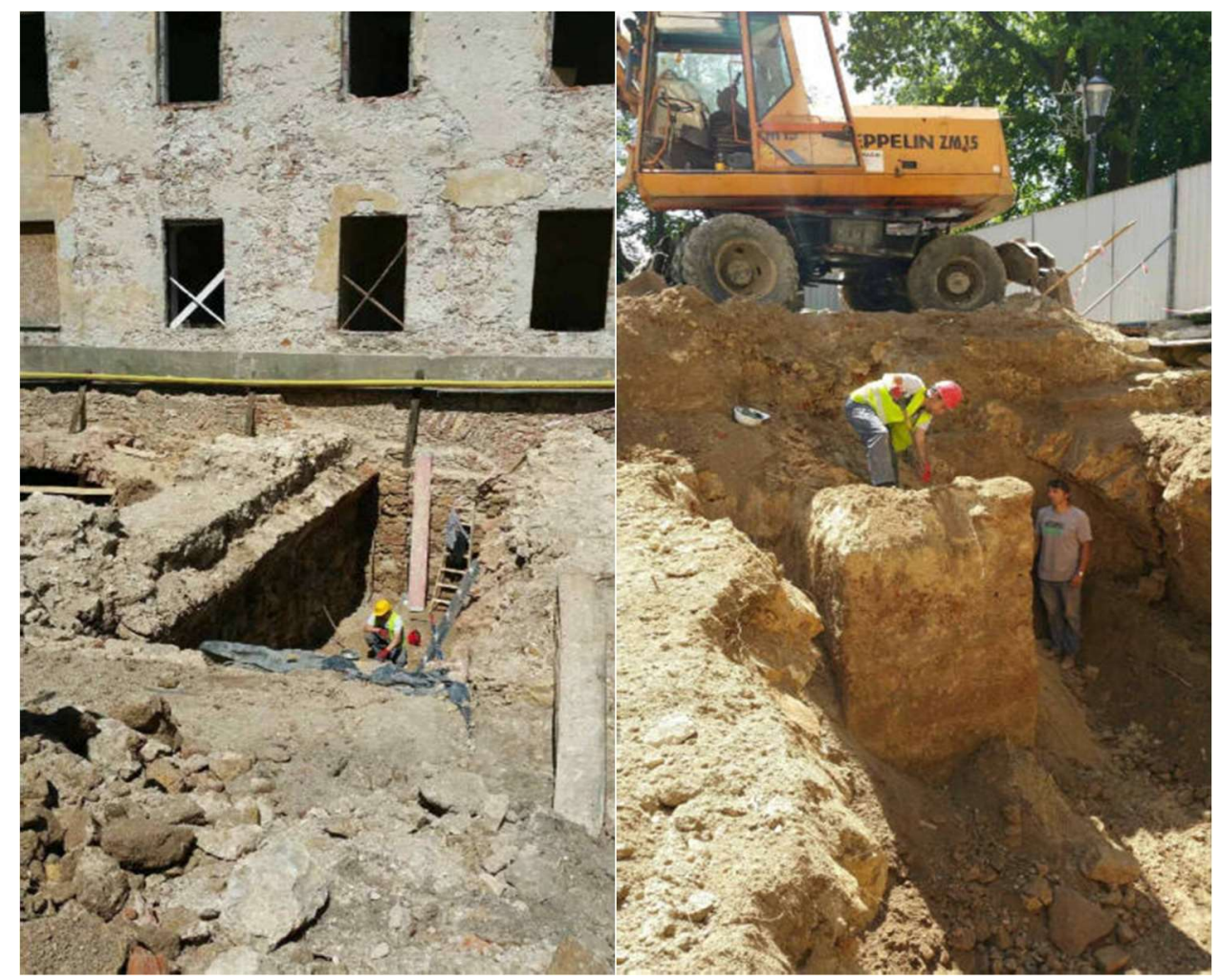

Fig. 10. Archaeological research and gradual uncovering of the space of buried medieval cellars under the courtyard. Likely to be fragments of hypocaust (Photo by the author)

After renovation, the complex will serve as an Educational, Conference and Cultural Centre. It is intended to inspire local cultural activities, remind people of history and be a place for meetings and various events. Inspire, on the scale of the whole town of Olkusz. The project concept to preserve the spatial shape of the 19th-century buildings, ensuring access and including in the entire complex the medieval cellars located under the surface of the courtyard and the main building. To this end, the renovation and reconstruction, adapting the former old town hall building to its new purpose were proposed as well as the construction of an exhibition pavilion in the courtyard and the reconstruction of the courtyard. 
The planned measures, in the case of the Old Starosty, mainly come down to the following:

- the removal of random building partitions and random interior decoration elements built for the former occupants,

- meeting the requirements of current building regulations

- adaptation works to its intended contemporary use.

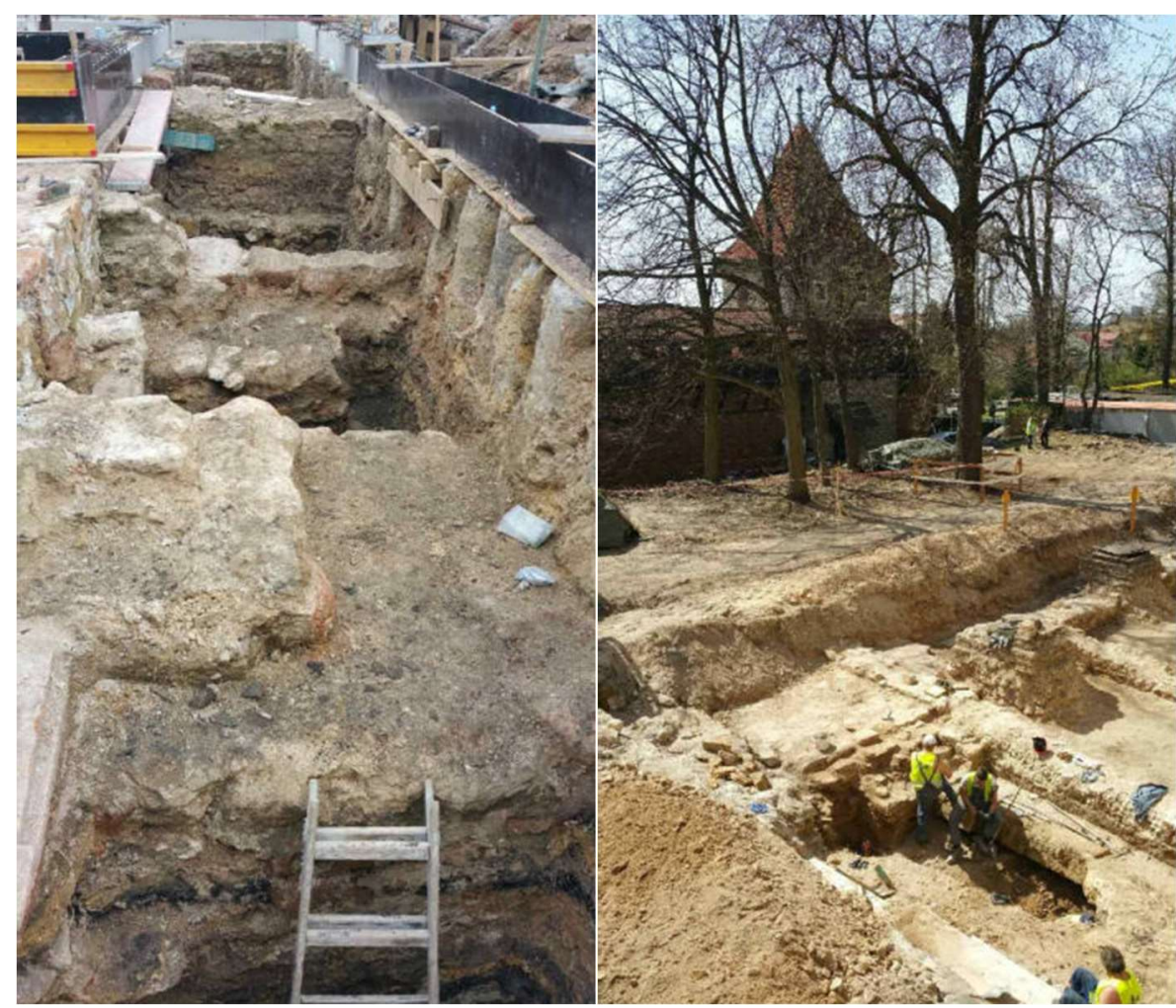

Fig. 11. Archaeological research and gradual uncovering of buried, medieval cellars under the courtyard (Photo by the author)

The idea was to create an internal courtyard as a place for events and to build a pavilion, functionally connected with the underground part of the Complex, intended for the exhibition of fragments of preserved relics. Formally, the new pavilion is designed as a glazed building with a section of brick wall and concrete cladding on both sides. The glazing allows visitors to see into the interior and observe the preserved fragments of the floor and portal. It also provides additional light to the underground corridor and a fragment of the preserved cellars. The 
pavilion is copped with a "green roof" of the reinforced concrete structure. The entire courtyard, bordered by the façade of the Old Starosty building, the pavilion building and a fragment of the rebuilt defensive walls, combined with the greenery of the existing trees and the greenery located on the roof of the pavilion building, is to create an interior with a distinctive atmosphere, intended for meetings, presentations, open-air events, chamber concerts and similar occasions. It can function as an open-air dining hall of a restaurant under the stars, a summer cinema, a multi-plan stage for concerts and performances. The complex as whole can comprehensively fulfil the programme connected with the organisation of events of a uniform nature, taking place in a simultaneous manner.

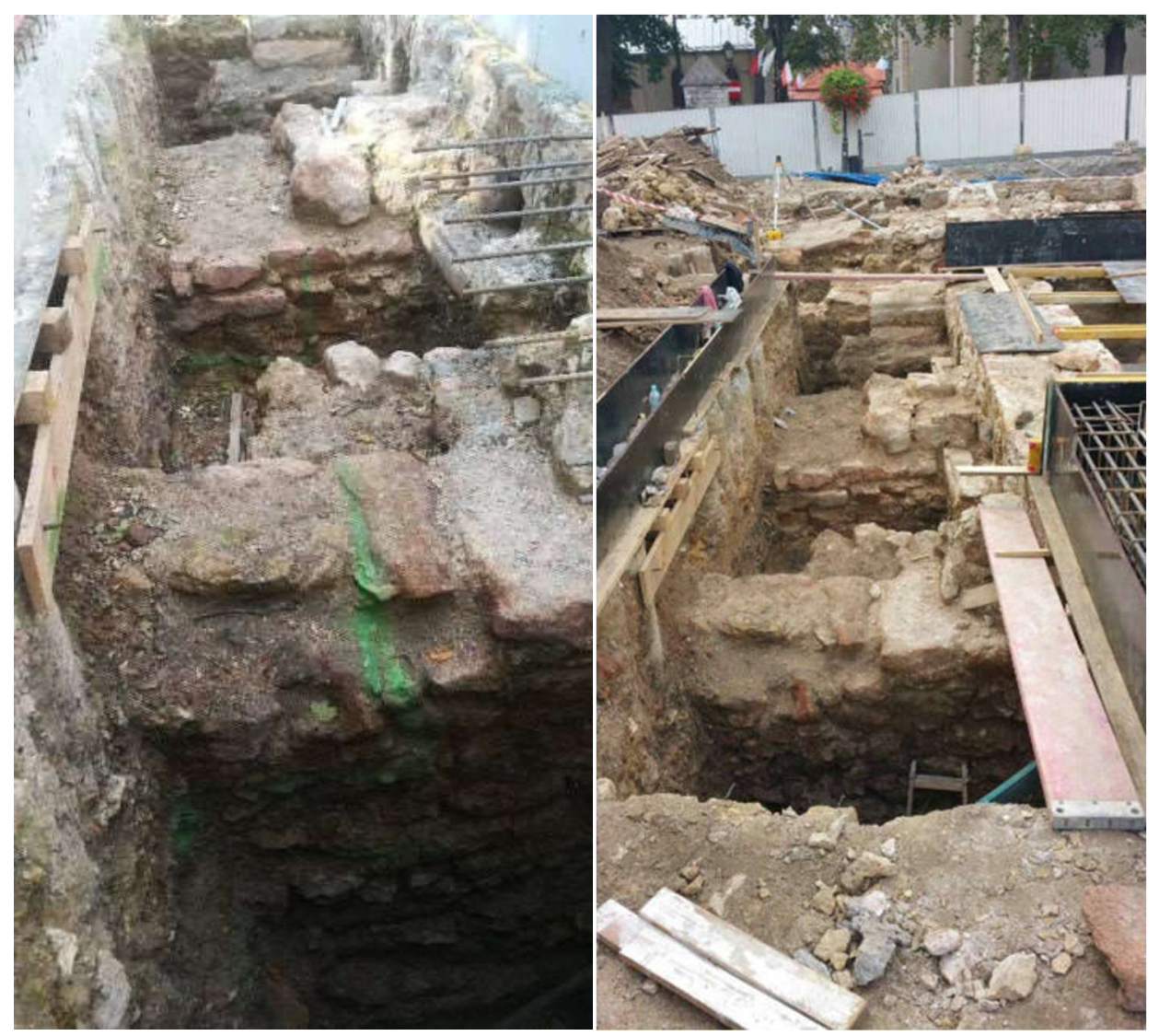

Fig. 12. Construction of load-bearing beams for the courtyard slab (at the same time the floor slab above the medieval cellars) (Photo by the author) 


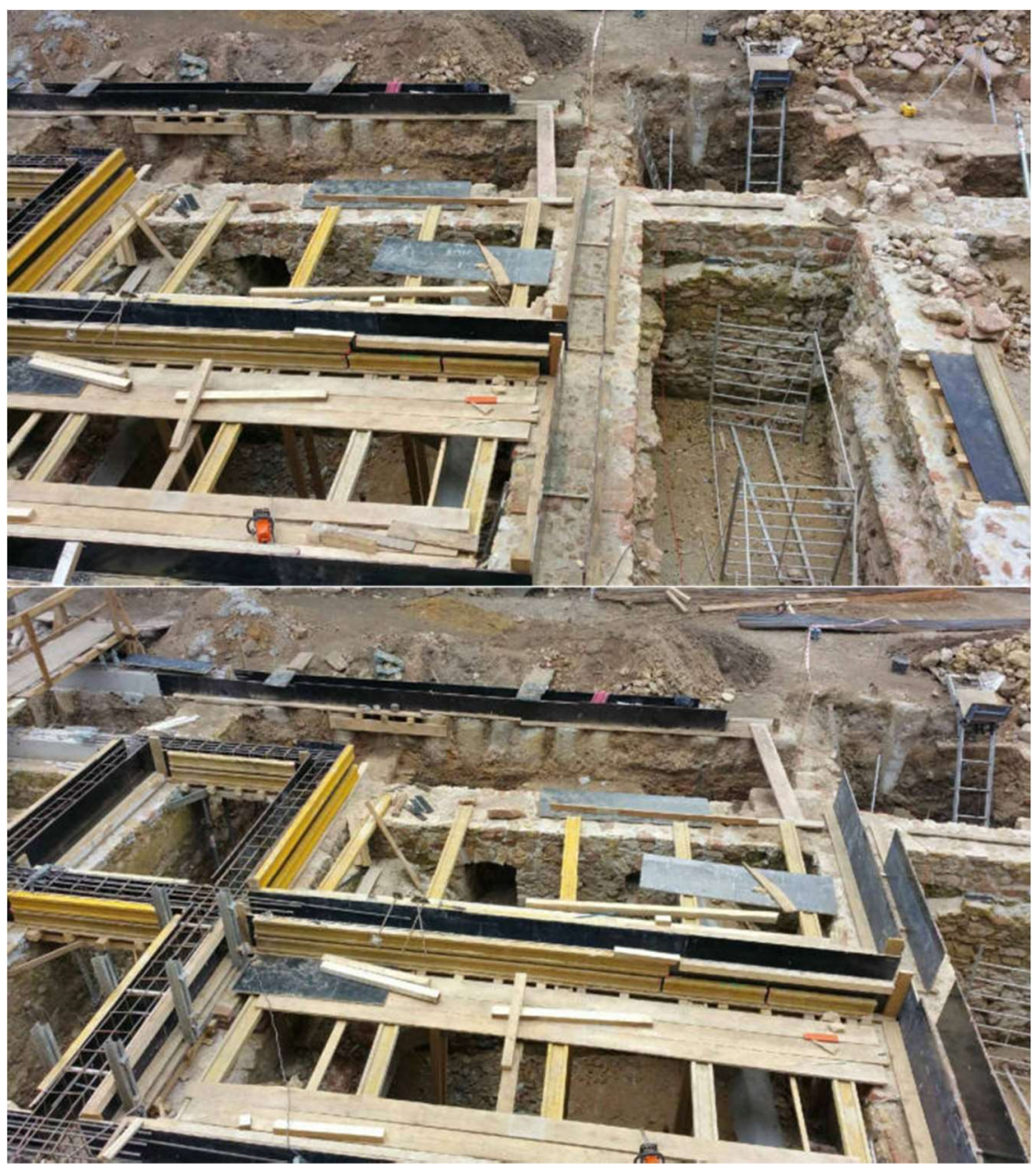

Fig. 13. Construction of the floor slab over the uncovered medieval cellars under the courtyard (Photo by the author) 


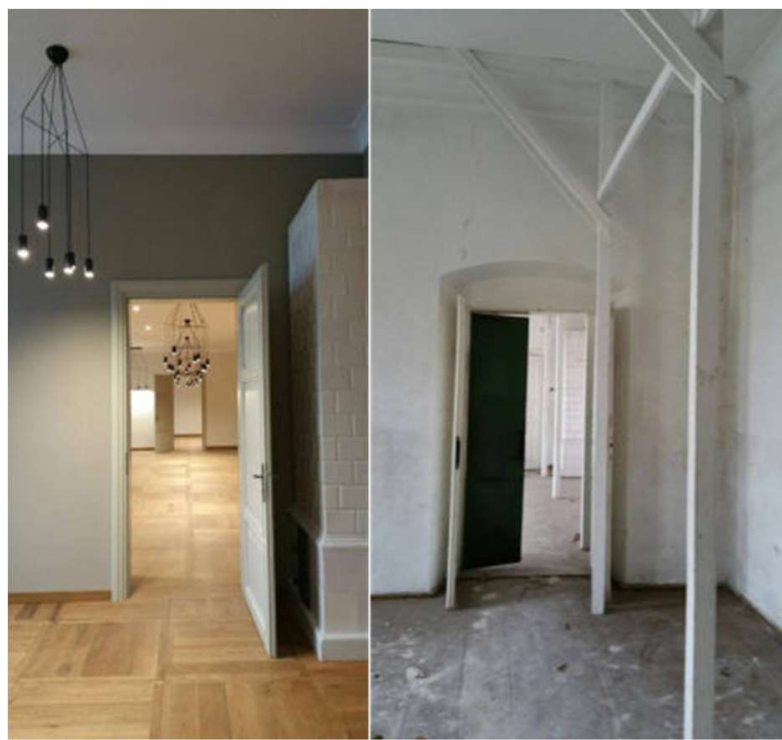

Fig. 14. The outfit reveals integrity or corruption... outward appearance is an extremely serious matter... clothing is the emblem of the soul. Writing this Thomas Carlyle formulated a kind of universal truth that inspires further comparisons. The external logic suggests the internal one, the absence of the external is the absence of the internal. The interiors of the Old Starosty rooms, in the enfilade arrangement: on the left before renovation, on the right after renovation (Photo by the author)

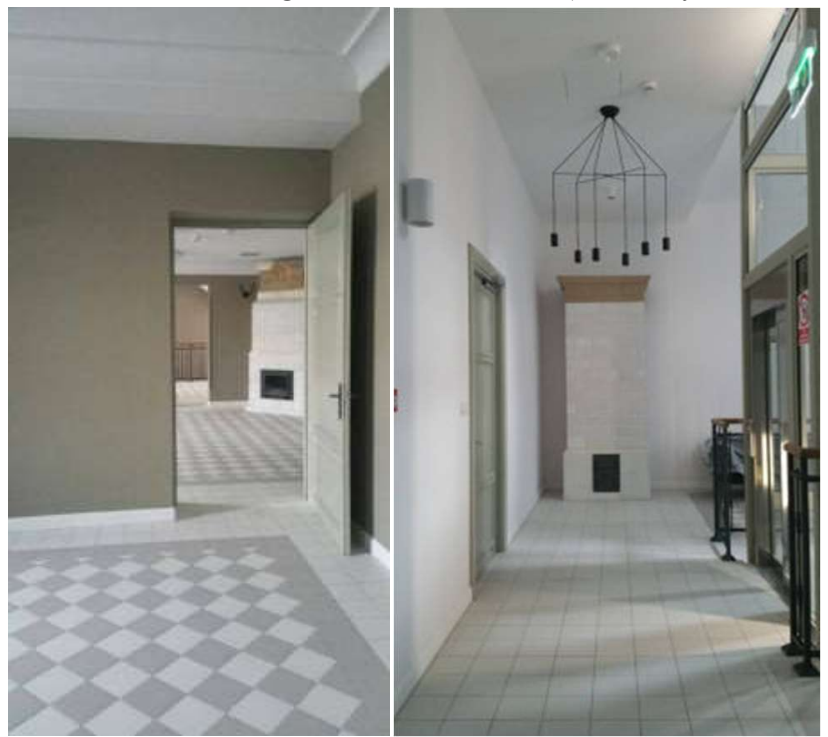

Fig. 15. The Old Starosty. Renovated interiors (Photo by the author) 


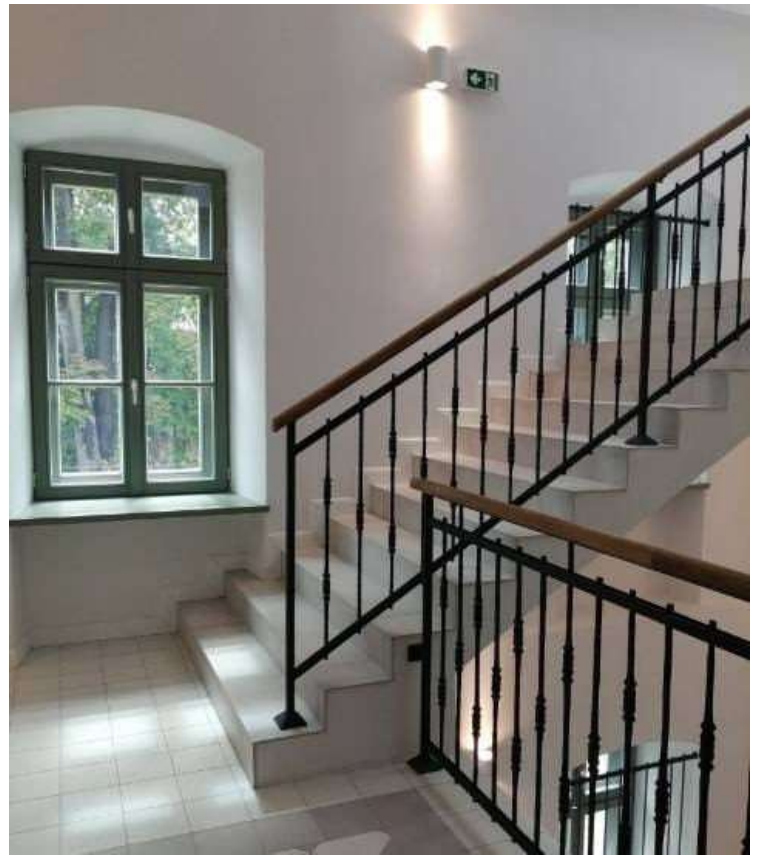

Fig. 16. Main staircase after renovation (Photo by the author)

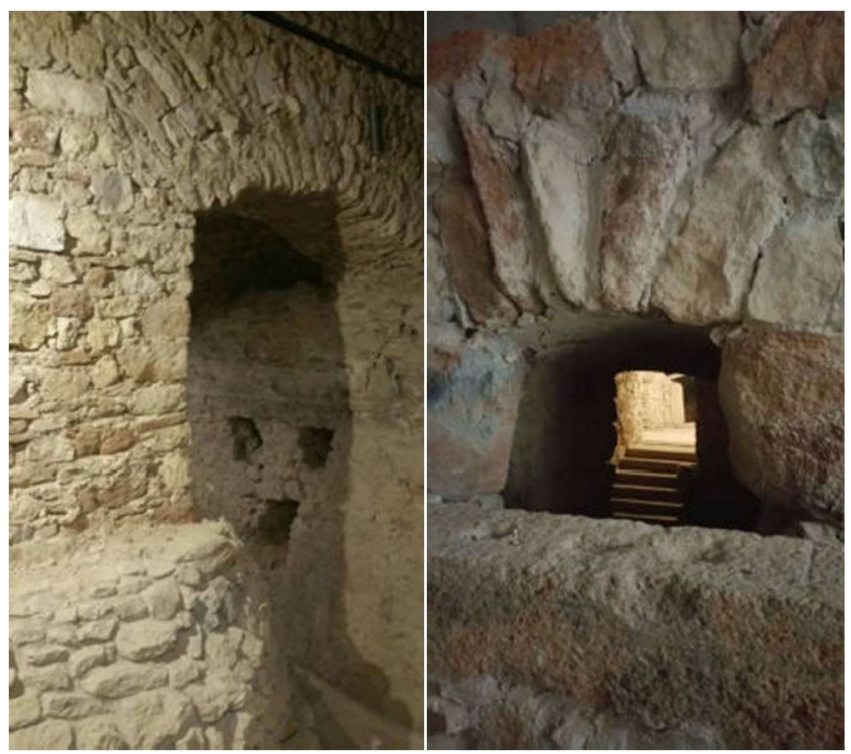

Fig. 17. Cellars after uncovering and renovation (Photo by the author) 


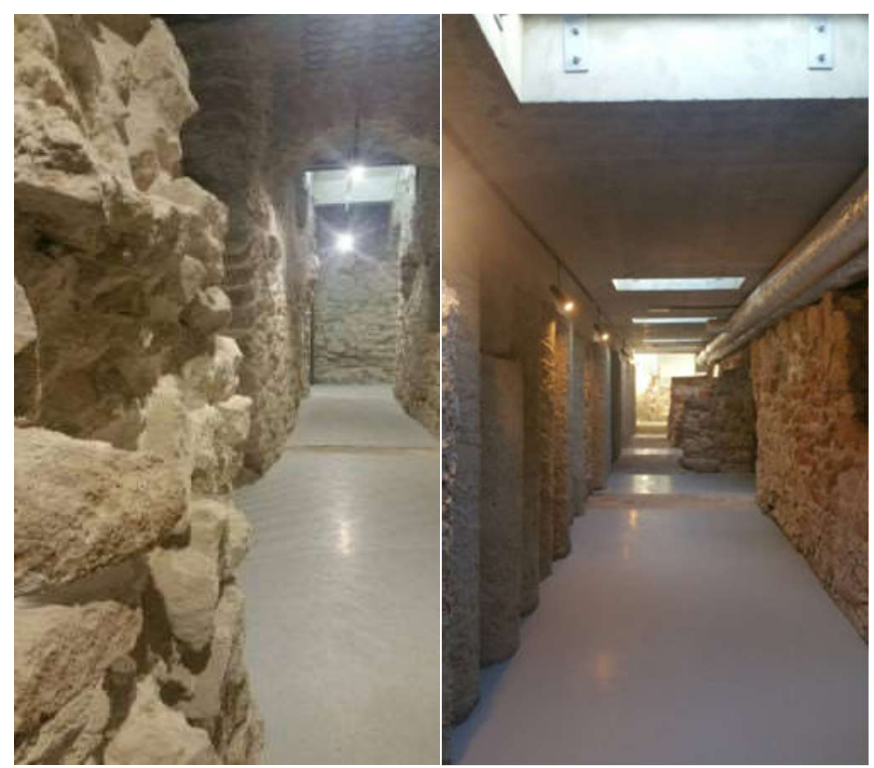

Fig. 18. Cellars after uncovering and renovation. Palisade retaining wall (on the right) (Photo by the author)

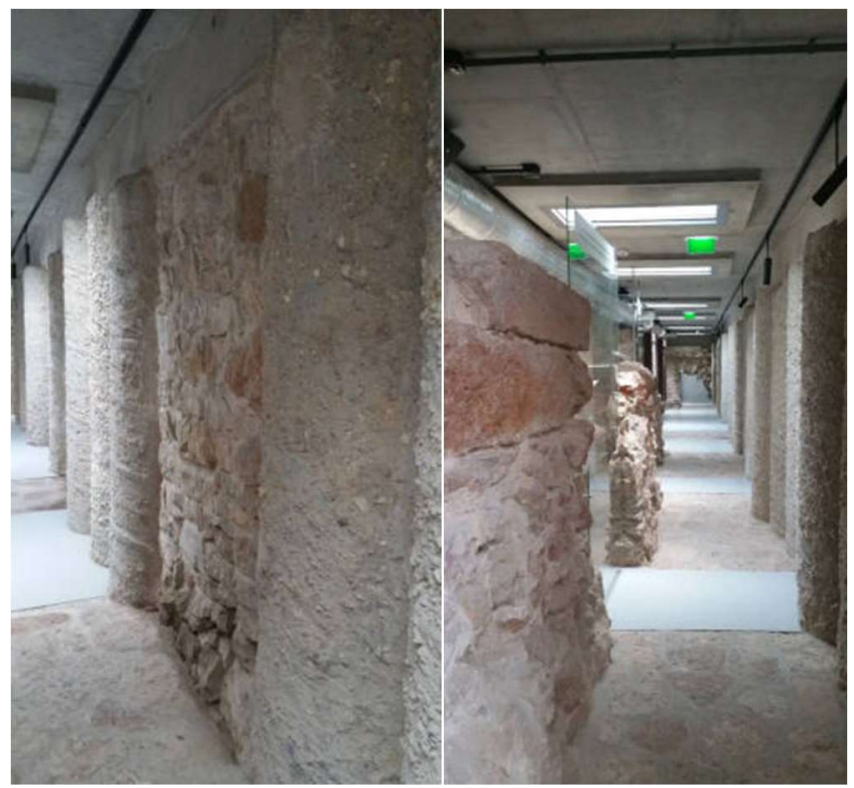

Fig. 19. Cellars under the courtyard, after uncovering and renovation. Palisade retaining wall - detail (on the left). The permanent exhibition rooms, naturally lit by skylights (on the right) (Photo by the author) 


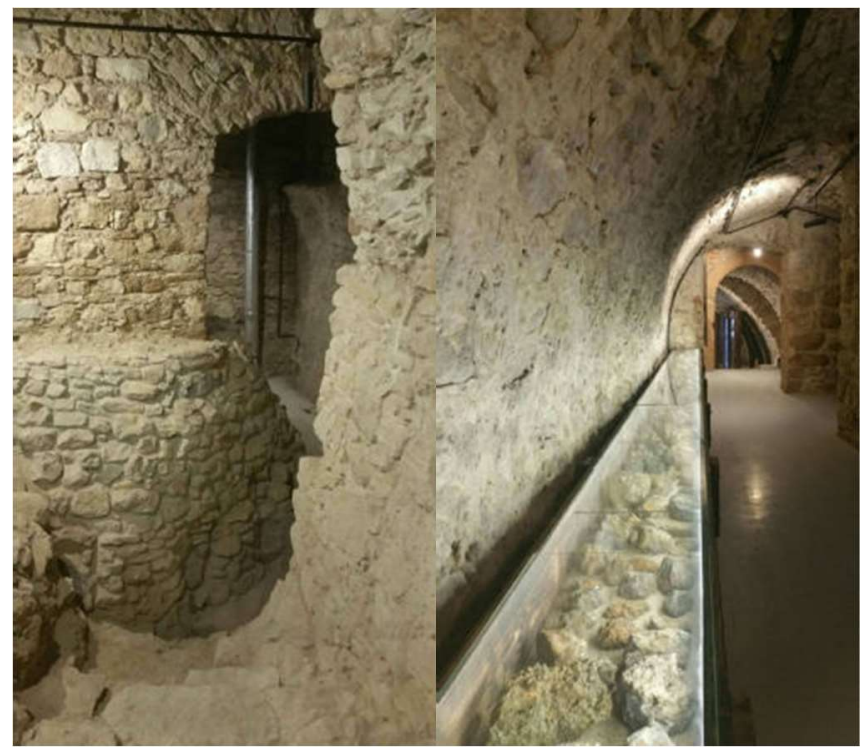

Fig. 20. Cellars under the main building, after uncovering and renovation (Photo by the author)

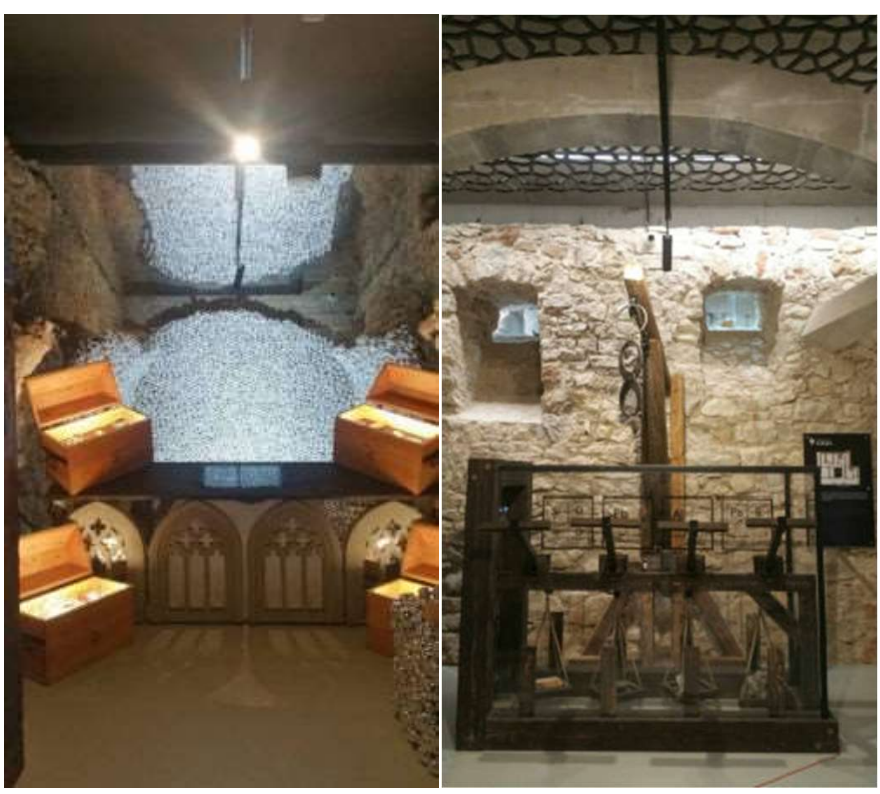

Fig. 21. Recollecting is linked to use of any historical space. Accepting the interpretation of such use is a determinant of demonstrating, which indicates the historical truth or subjectively interpreting - pretends it. Layout of the exhibition area of the former royal mint (Photo by the author) 


\section{A SYNERGY OF BUILDING ANATOMY, EMANATION AND STAFFAGE. BODY, CLOTHING AND SOUL}

According to Thomas Carlyle, outward appearance is an extremely serious matter, not only because of what it makes 'transparent', but also because the wrong one, can in unfavourable social conditions, turn us into a bad personclothing is the emblem of the soul [2]. By writing this, Thomas Carlyle formulated a kind of universal truth that inspires further comparisons. The external logic suggests the internal one, the absence of the external is the absence of the internal. The outfit reveals integrity or corruption. It can indicate righteousness and aesthetic harmony or demagogically demoralise the user and the observer. Its incompatibility with the interior suggests lying. Clothing is a part of an architectural object, the outfit, i.e., external appearance is its skin [7].

In the case of renovation of historical buildings, the key is their current and future use. Nowadays, their historical use can often not be maintained due to social, economic, or cultural changes. The buildings, which are a kind of enclosure for the structures realising them and being their material emanation, have lost their previous use values without losing their cultural significance. The inadequacy of the internal space separation to the organisational structure of the building's users results in the loss of the specific synergy that builds the ambiguous coherence of the building. That applies to the anatomy of the building (body) and its nonmaterial, multifaceted emanation (soul). The body is dressed in a noncontemporary staffage of clothing.

That also applies to the Old Starosty building in Olkusz. Erected on the relics of a medieval royal mint as a building for the regional commissioner, it originally had an administrative purpose, which is gradually lost. The modern organisation of the local administration structure rendered it completely obsolete. The last episode before the complete abandonment, which, in addition to the lack of ongoing maintenance and repairs, contributed to the progressive degradation, was the exploitation of the building by several tenants.

It is crucial to make a decision directing the actions concerning the future appearance, shaping the overall aesthetics of the object. For the aboveground parts of the Old Starosty building, it was decided that the existing elements would be renovated, and where they were significantly damaged or missing-that they would be reconstructed in the spirit in which the object was created. That was the case, for example, with flooring, plaster and some detail elements (balustrades, joinery, etc.). Since the historical elements of the wooden ceiling structure were preserved and the natural texture of the attic truss texture was displayed, and the 
overall increase of the building's volumetric space as a result of the inclusion of the medieval cellars in the complex, an additional problem was to meet the necessary requirements arising from the need to ensure the safety of the building users. That involved, among other things, additional ceiling protection with double fire partitions, which led to a partial reduction in the height of the storeys. Fire partitioning was also made in the basement and attic. The medieval cellars under the building and the courtyard were covered with soil and rubble and mostly inaccessible. The area under the building was cleared of debris and covered with local reinforced concrete slabs. Making the part under the courtyard accessible to the public was connected with constructing a uniform covering of the whole with a reinforced concrete slab, which at the same time is the foundation for the courtyard floor. That allowed some of the surviving historical vaults to be preserved and displayed. It is supplemented by staffage - an exhibition of elements found during archaeological research and an educational exposition of exhibits recreating the times of historic mining in Olkusz.

The effect of the toady's model of use is a unique synergy in the revaluation of meanings: the anatomy of a building, its non-material emanation and staffage.

\section{REFERENCES}

1. Adler, M J 1995. Ten Philosophical Mistakes (Dziesięć błędów filozoficznych). Warszawa: Medium.

2. Carlyle, T 2000. Sartos Resartus. University of California Press.

3. de Leyva JLT, 2004. WritingOverWriting. Czasopismo Techniczne, Iss.10$\mathrm{A} / 2004$ year 101 .

4. Kant, I 1957. Kritik der reinen Vernunft (Krytyka czystego rozumu). Warszawa: PWN.

5. Kasprowicz M. The set of the historical elements. The history of the object (Zastawienie elementów historycznych. Historia obiektu). - Pracownia Projektowa „ARCH” [,ARCH” Design Firm], Marta Kasprowicz.

6. Mironowicz, I, 2013. Between self-organization and policies (Między samoorganizacja a planowaniem).

7. Nawrot, G 2021, Interpretative constructing of architectural space. Façade vs structure. Image or System. (Interpretacyjne konstruowanie przestrzeni architektonicznej. Fasada a struktura. Obraz bądź system). Builder 4,285. DOI:10.5604/01.30010014.7925

8. Nawrot, G 2015. On Contemporary Forms of Dwelling in the City. ( $O$ wspótczesnych formach zamieszkiwania w mieście). Gliwice.

9. Sudjic, D 2015. The Edifice Compex. The Architecture of Power (Kompleks gmachu. Architektura władzy). Warszawa: Centrum Architektury.

10. Weber, M 1994. Sociological Writings. ed. by Wolf Heydebrand. Continuum. 
Editor received the manuscript: 11.06.2021 